\title{
PENINGKATAN DAYA SAING BRIKET ARANG BATOK KELAPA MELALUI PENDAMPINGAN MANAJEMEN PRODUKSI, PEMASARAN DAN KEUANGAN PADA USAHA BRIQCO DAN D'BRIQUETTES DI KABUPATEN BANTUL
}

\author{
Diyah Candra Anita ${ }^{*}$, Retno Wulandari ${ }^{2}$, Hendrato Setiabudi Nugroho $^{3}$ \\ ${ }^{1}$ Program Studi Keperawatan, Fakultas Ilmu Kesehatan, Universitas 'Aisyiyah Yogyakarta, Yogyakarta, Indonesia \\ ${ }^{2}$ Program Studi Agrobisnis, Fakultas Pertanian, Universitas Muhammadiyah Yogyakarta, Yogyakarta, Indonesia \\ ${ }^{3}$ Program Studi Manajemen, Fakultas Ekonomi, Ilmu Sosial dan Humaniora, Universitas 'Aisyiyah Yogyakarta, \\ Yogyakarta, Indonesia \\ *Penulis korespondensi: diyah.candra@gmail.com
}

\begin{abstract}
Abstrak
Unit Kegiatan Masyarakat (UKM) briket arang batok kelapa mempunyai peluang ekspor yang cukup besar. Kebutuhan akan briket arang oleh negara Barat dan Timur Tengah mendorong permintaan luar negeri semakin meningkat. Dua UKM di Bantul yang sudah melakukan ekspor produk briket arang kelapa adalah BriqCo dan D'Briquettes. Kedua UKM tersebut mempunyai permasalahan yaitu permasalahan pengelolaan keuangan yang masih konvensional, belum maksimalnya penggunaan internet dan perlunya peningkatan kapasitas produksi. Metode yang dilakukan untuk mengatasi permasalahan tersebut adalah pelatihan dan pembelian software akuntasi untuk memudahkan pembukuan keuangan. Metode yang dilakukan untuk mengatasi masalah minimnya penggunaan internet yaitu dilakukan pemasangan Wifi dan pendampingan secara intensif dalam penggunaan internet untuk tujuan bisnis. Metode yang dilakukan untuk mengatasi masalah peningkatan produksi yaitu dengan pembuatan belt conveyor yang dapat menambah kecepatan dan jumlah produksi.
\end{abstract}

Kata kunci: Briket arang batok kelapa, Manajemen keuangan, Software akuntansi, Pelatihan internet, Mesin belt conveyor

\begin{abstract}
The Small and Medium Enterprise (SME) of coconut shell charcoal briquettes has considerable export opportunities. The need for charcoal briquettes by Western and Middle Eastern countries has pushed foreign demand to increase. Two SMEs in Bantul that have exported coconut charcoal briquettes are BriqCo and D'Briquettes. The two SMEs have problems, namely the problem of still conventional financial management, not yet the maximum use of the internet and the need to increase production capacity. The method used to overcome these problems is training and purchasing accounting software to facilitate financial accounting. The method used to overcome the problem of the minimal use of the internet is the installation of Wifi and intensive assistance in the use of the internet for business purposes. The method used to overcome the problem of increasing production is by making conveyor belts that can increase the speed and amount of production.
\end{abstract}

Keywords: Coconut shell charcoal briquettes, Financial management, Accounting software, Internet training, Machines conveyor belt

\section{PENDAHULUAN}

Adanya pasar global sudah menjadi hal yang tidak dapat dihindarkan dan harus dihadapi oleh pengusaha Indonesia terutama UKM (Usaha Kecil \& Menengah). Meski banyak tantangan dan bahaya yang harus dihadapi, UKM sebenarnya mempunyai peluang untuk memperoleh keuntungan dari pasar global. Dengan strategi yang tepat dan benar, UKM Indonesia dapat bersaing dengan UKM-UKM di negara-negara berkembang lainnya khususnya di Asia Tenggara untuk masuk dan diterima di pasar global (Downing \& Campbell, 2014).

Ancaman yang membayangi UKM yang mencoba masuk ke pasar global sebenarnya siginifikan. Mereka terancam ke dalam pertarungan yang justru menuju ke dasar jurang kehancuran. Hal ini disebabkan oleh beberapa faktor, yaitu saling menjatuhkan harga jual sesama produsen padahal biaya bahan baku yang semakin mahal, harga jual dari UKM sejenis dari luar negeri jauh lebih murah, tingginya upah tenaga kerja 
dan minimnya dukungan pemerintah sendiri (Arfani, 2013).

Namun bagi UKM yang sukses masuk ke pasar global, keuntungan yang diperoleh sangat besar terutama dari selisih kurs mata uang. Hal ini disebabkan biaya produksi memakai mata uang rupiah sedangkan keuntungan yang diterima menggunakan mata uang dollar. Sehingga keuntungan yang diterima berkalikali lipat. Asalkan tidak ada resesi dunia yang mengancam. Hal ini yang menyebabkan terkadang banyak yang tergiur dengan keuntungan dari pasar global namun karena tidak tahu caranya bertahan di pasar global justeru gulung tikar lebih cepat (Arfani, 2013).

Oleh karenanya diperlukan sebuah metode yang tepat dan sistematis yang dapat digunakan oleh UKM untuk dapat masuk dan bertahan di pasar global. Metode tersebut adalah Global Value Chain atau sering disingkat GVC. Sebuah metode yang sudah diterapkan di pelbagai negara serta sudah terbukti keberhasilannya. Global Value Chain adalah cara yang mudah diterapkan untuk UKM sehingga ia dapat segera naik ke level yang lebih tinggi. Keberhasilan dari metode GVC ini dapat diterapkan ke UKM yang berorientasi pada ekspor (Kula et al, 2006).

Salah satu UKM yang sedang berkembang dan mempunyai peluang ekspor yang cukup besar di pasar global adalah briket arang batok kelapa. Permintaan akan briket arang mulai masuk ke Indonesia pada awal tahun 2000-an. Produk briket banyak dibutuhkan di Eropa, Amerika dan Timur Tengah. Di Eropa dan Amerika, briket arang batok kelapa dibutuhkan sebagai bahan bakar untuk barbeque, sedangkan di Timur Tengah, briket arang digunakan sebagai bahan bakar untuk rokok sissa. Hal ini yang mendorong permintaan dari luar negeri lumayan banyak sehingga memunculkan pengusaha-pengusaha briket arang batok kelapa (Dunn et al., 2006).

Di Yogyakarta, terdapat sejumlah UKM yang memproduksi briket arang batok kelapa, diantaranya adalah BriqCo dan D'Briquettes. Keduanya berada di Kabupaten Bantul. BriqCo berada di Kecamatan Sewon sedangkan D'Briquettes berada di Kecamatan Pleret. Dua UKM ini cukup sukses untuk ukuran industri kecil yang menembus pasar global. Mereka berhasil mengubah batok kelapa yang awalnya tidak begitu dilirik menjadi peluang yang luar biasa. Pemiliknya bahkan orang desa biasa yang awalnya tidak paham dengan pasar global. Bukan sarjana yang mempelajari pasar global.

UKM BriqCo mulai dirintis oleh Novi Setiawan sejak tahun 2009. Berawal dari usaha coba-coba, Novi Setiawan untuk membuat briket dari arang batok kelapa. Usaha coba-coba ini muncul setelah Novi mendapatkan tawaran dari temannya yang mendapat pesanan dari luar negeri. Setelah itu, Novi selalu mendapat pesanan dari luar negeri. UKM
D’Briquettes mulai dirintis oleh pemiliknya, Danang Setiyo pada tahun 2012. Sebelumnya Danang Setiyo terlebih dahulu sudah bekerja di BriqCo. Lalu di tahun 2012, Danang memberanikan diri mencoba mengembangkan usahanya sendiri dan mendapat dukungan dari Novi.

Pada saat awal survei, tim peneliti telah melakukan analisa situasi terhadap dua UKM briket arang batok kelapa, yaitu BriqCo dan D'Briquettes. BriqCo masih menerapkan manajemen keuangan yang sederhana. Sistem keuangan masih diakukan dengan metode pencatatan yang sederhana sehingga banyak transaksi tidak tercatat. Hal ini merupakan kerugian yang besar karena ada transaksi-transaksi yang tidak tercatat. Untuk BriqCo, pengendalian manajemen keuangan dibantu oleh istri dari pemilik. D'Briquettes juga mengandalkan pencatatan sederhana. Pengendalian manajemen perusahaan terpusat pada satu orang saja dibantu oleh seorang mandor. Namun D'Briquettes mempunyai tim marketing yang mempunyai akses ke para buyer. Tim marketing inilah yang menggantikan trader. Akan tetapi selama ini belum ada pembinaan dan peningkatan kualitas motivasi karyawan.

Dalam manajemen keuangan, permasalahan yang dihadapi adalah pencatatan uang keluar dan masuk belum mengikuti tata kaidah dalam akuntansi sehingga pemilik tidak mengetahui keuntungan yang ia peroleh. Oleh karenanya, dibutuhkan sistem pembukuan dan akuntansi yang sederhana khusus untuk UKM. BriqCo dan D'Briguettes menerapkan manajemen keuangan yang sederhana dan belum menggunakan sistem akuntansi terutama akuntansi untuk UKM. Perencanaan produksi juga belum masuk menjadi bagian dari sistem. Manajemen masih sederhana dan konvensional sehingga tidak mengetahui berapa cash flow, pengupahan mingguan, belum terdaftar sebagai wajib pajak, membuat mesin sendiri. Permasalahan lain yang ditemui pada kedua mitra adalah masih minimnya penggunaan internet untuk tujuan bisnis.

Permasalahan lain yang dihadapi adalah peningkatan kapasitas produksi. Kapasitas produksi BriqCo saat ini mencapai maksimum 1,8 ton perhari sedangkan D'Briquettes mencapai maksimum 4,5 sampai dengan 5 ton perhari. Rendahnya kapasitas produksi dari BriqCo disebabkan keterbatasan suplai arang batok kelapa dan kapasitas mesin produksi. Berbeda dengan D'Briquettes yang sudah mampu menghasilkan briket dengan jumlah yang besar. Akan tetapi karena tidak adanya mesin mixer dan mesin conveyer, pengolahan di BriqCo menjadi lambat. Tujuan umum dalam kegiatan pengabdian ini adalah meng-upgrade UKM briket arang batok kelapa supaya lebih memiliki peluang masuk ke pasar global.

\section{METODE}

Kegiatan yang dilakukan disesuaikan dengan pemecahan permasalahan. Dalam memecahkan permasalahan manajemen keuangan yang masih 
sederhana diperlukan peningkatan pengetahuan dan peningkatan manajemen keuangan. Kegiatan dilakukan melalui workshop dan pendampingan pengelolaan keuangan menggunakan software akuntasi. Pendekatan yang dilakukan untuk mendukung realisasi program terbagi menjadi tiga, yaitu pemberian materi, pelatihan (demonstrasi), pendampingan dan pembimbingan. Pemberian materi dilakukan dengan memberikan materi secara verbal maupun visual, pelatihan (demonstrasi) dilakukan melalui pelatihan penggunaan software akuntansi secara langsung, serta kegiatan pendampingan dan pembimbingan bertujuan supaya kelompok mitra dapat menggunakan software yang sudah dijelaskan dan didemonstrasikan. Pendekatan yang dilakukan untuk mengatasi minimnya penggunaan internet yaitu dengan pembimbingan dan pendampingan penggunaan internet untuk tujuan bisnis. Sedangkan untuk dalam memecahkan permasalahan peningkatan kapasitas produksi dilakukan dengan pengadaan mesin conveyer dan pengadaan oven permanen.

\section{HASIL DAN PEMBAHASAN}

\subsection{Mengatasi Permasalahan Pembukuan Keuangan}

Mitra dalam hal ini ialah UKM produsen briket arang batok kelapa BriqCo di Sewon Bantul dan D'Briquettes di Pleret Bantul. Pada UKM BriqCo, sistem pencatatan keuangan masih amat sederhana dan terkadang tidak rapi sehingga tidak mengetahui secara pasti keuntungan yang diperoleh. Sedangkan pada UKM D'Briquettes, owner membutuhkan sistem akuntansi yang baik untuk menjaga dan memelihara pencatatan transaksi mereka. Dari permasalahan kedua mitra tersebut maka diperlukan beberapa solusi. Solusi yang disepakati bersama mitra adalah: (1) Perlu diadakannya pencatatan transaksi keuangan yang sesuai dengan kaidah akuntansi. Oleh karena itu, perlu diadakannya pelatihan terkait akuntansi untuk UKM sehingga mereka akan mudah untuk mencatatkan transaksi dan segera mengetahui cashflow usaha mereka; (2) Perlu dibuatkan software khusus untuk akuntansi UKM berorientasi ekspor sehingga dapat digunakan dengan mudah dan sederhana sehingga mereka dapat mendokumentasikan dan membuat pembukuan yang baik; (3) Pengadaan mesin conveyer untuk meningkatkan kapasitas produksi.

UKM produsen briket arang batok kelapa BriqCo di Sewon Bantul dan D'Briquettes sebagai peserta dalam pelatihan dan pendampingan penggunaan software akuntasi. Masing-masing mitra mengirimkan dua orang untuk mengikuti pelatihan. Setelah dilakukan pelatihan selanjutkan dilakukan pendampingan penggunaan software akuntasi dengan menggunakan komputer yang ada di masing-masing mitra. Guna menyelesaikan permasalahan pembukuan, mitra terutama BriqCo diminta untuk segera melakukan rekruitmen karyawan dengan lulusan SMK akuntansi, yang akan diperkerjakan di bagian pembukuan. Pembukuan terdiri dari dua hal, yaitu: pembukuan akuntansi keuangan dan pembukuan produksi.
Beberapa kendala terjadi karena rekruitmen di BriqCo terjadi dalam waktu selama dua bulan. Selama rentang dua bulan itu, karyawan akuntansi yang direkrut hanya bekerja selama tiga minggu, dengan alasan memperoleh pekerjaan di tempat yang lain. Hal tersebut mengakibatkan BriqCo mengulang proses rekruitmen kembali.

Kondisi yang sama juga terjadi pada pabrik d'Briquettes. Karyawan akuntansi pada pabrik tersebut sebelumnya sudah ada, namun dikarenakan konflik internal antara karyawan, mengakibatkan karyawan akuntansi di pabrik d'Briquettes akhirnya keluar. Pabrik D'briquettes kemudian merekrut karyawan akuntansi yang baru.

Tim pengusul bersama mitra sepakat untuk membeli sebuah software akuntansi untuk bisnis, yaitu Zahir Accounting. Software Zahir memiliki beberapa keunggulan, diantaranya: (1) Mampu menentukan keputusan bisnis dengan tepat dan cepat; (2) Mengetahui kondisi keuangan bisnis setiap saat; (3) Bekerja menjadi lebih nyaman, dikarenakan display antarmuka lebih menarik; (4) Mengelola hutang dan piutang dengan mudah. Seluruh hutang piutang jatuh tempo dan giro mundur akan ditampilkan dalam bentuk reminder dan grafik yang mudah dipahami; (5) Memudahkan pengelolaan persediaan secara lengkap; serta (6) Jaminan Software dan Layanan Purna Jual.

Tim pengusul menyarankan pembelian software accounting disebabkan karena proses pembukuan menggunakan Microsoft excel rawan terhapus, dan apabila terhapus akan menyebabkan seluruh data pembukuan hilang. Lain halnya jika menggunakan software. Software akan tetap menyimpan data pembukuan yang dilakukan dengan terkategori bulan per bulan. Pembelian software dilakukan pada akhir bulan Mei 2018 dengan dua license yaitu BriqCo dan d'Briquettes, dan pelatihan penggunaannya dilakukan pada 11 Juli 2018 di Universitas 'Aisyiyah Yogyakarta. Dilanjutkan dengan pelatihan privat ke pabrik masing-masing untuk melihat progress pengembangannya selama empat kali kunjungan privat, yaitu bulan Juli, Agustus, September dan Oktober 2018.

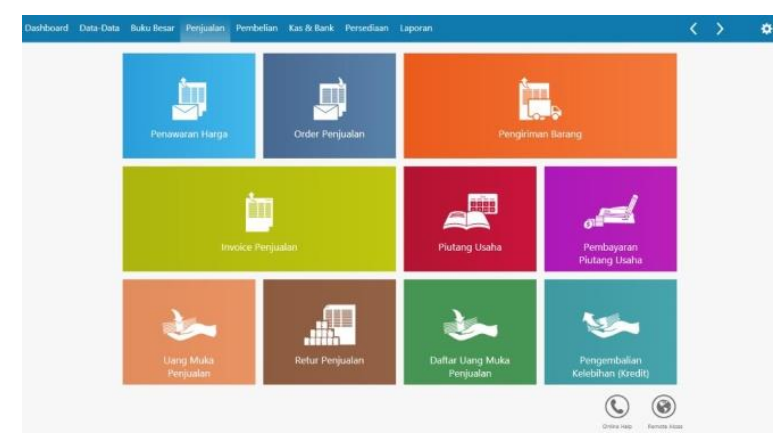

Gambar 1. Fitur Software Akuntansi Zahir 


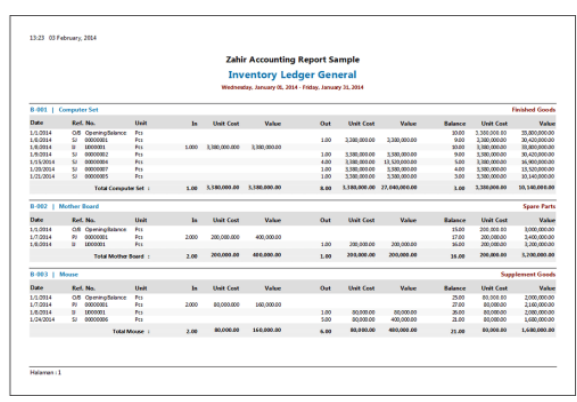

Gambar 2. Hasil Pembukuan Dengan Menggunakan Software Zahir

\subsection{Mengatasi Permasalahan Internet}

Salah satu masalah pada BriqCo adalah penggunaan internet yang belum maksimal untuk tujuan bisnis. Solusi yang ditawarkan adalah dengan memberikan pembimbingan dan pelatihan secara intensif dalam penggunaan internet serta pemasangan Wifi Speedy.

Adanya internet semakin memudahkan owner untuk mencari informasi perkembangan harga briket di pasar global. Karyawan juga sangat terbantu untuk mengakses internet saat bekerja, guna mendapatkan informasi yang mendukung produksi briket.

Pelatihan mengenai optimalisasi penggunaan internet dilakukan secara privat pada dua UKM. Pelatihan ini sampai pembuatan website, namun kemudian pelatihan ini dihentikan karena owner khawatir permintaan produksi briket akan meningkat sementara kapasitas produksi belum memadai.

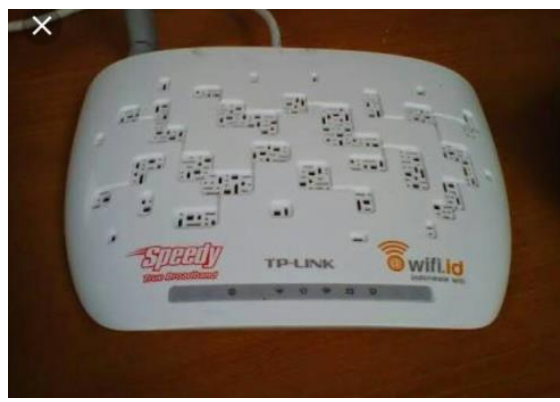

Gambar 3. Wifi Speedy Yang Dipasang

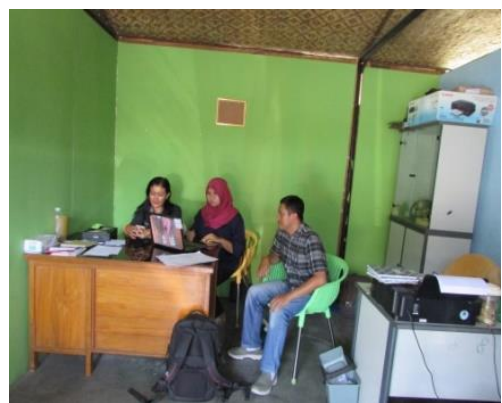

Gambar 4. Pelatihan Internet Secara Privat

\subsection{Mengatasi permasalahan kapasitas produksi}

Permasalahan lain pada kedua mitra adalah memenuhi demand kuantitas ekspor dari pembeli yang belum terpenuhi sampai dengan saat ini. Oleh karena itu, untuk mengatasi masalah tersebut, mitra bersama pengusul sepakat untuk melakukan pengadaan mesin bagi pabrik.

Belt conveyor atau ban berjalan adalah peralatan yang cukup sederhana yang digunakan untuk mengangkut curah dengan kapasitas besar. Alat ini terdiri dari sabuk yang tahan terhadap pengangkut benda padat. Sabuk yang digunakan pada belt conveyor dibuat dari jenis karet yang dibeli di Jakarta dengan kualitas prima. Belt conveyor dikonsep pada bulan Februari 2018, pengadaan bahan selama bulan Februari sampai dengan Mei 2018. Belt conveyor sederhana dirancang berdasarkan jurnal teknisi dan dirakit bersama tim pengusul dengan menggunakan alat-alat sederhana. Belt conveyor dibuat oleh teknisi local pada bulan Juni 2018, dan mulai digunakan pada bulan tersebut.

Belt conveyor yang dibuat sudah dievaluasi penggunaannya selama satu bulan. Hasil evaluasi menunjukkan belt conveyor mampu meningkatkan kecepatan produksi sampai dengan $85 \%$. Rata-rata produksi briket meningkat menjadi $500 \mathrm{~kg} / \mathrm{jam}$, dari semula $300 \mathrm{~kg} / \mathrm{jam}$. Peningkatan kecepatan produksi ini membuat pekerjaan memotong dan mencetak briket yang seharusnya dilakukan selama 6 jam dapat direduksi, sehingga hal tersebut dapat dikerjakan dalam waktu 4 jam.

Permasalahan yang datang berikutnya adalah kecepatan penggunaan belt conveyor ternyata tidak diimbangi dengan kecepatan pada pengayakan bahan. Mesin ayakan hanya satu, sehingga belum mampu mengimbangi kecepatan belt conveyor. Kendala yang lainnya juga jumlah oven yang hanya satu sehingga briket yang sudah dipercepat dengan belt conveyor belum bisa langsung dikeringkan.

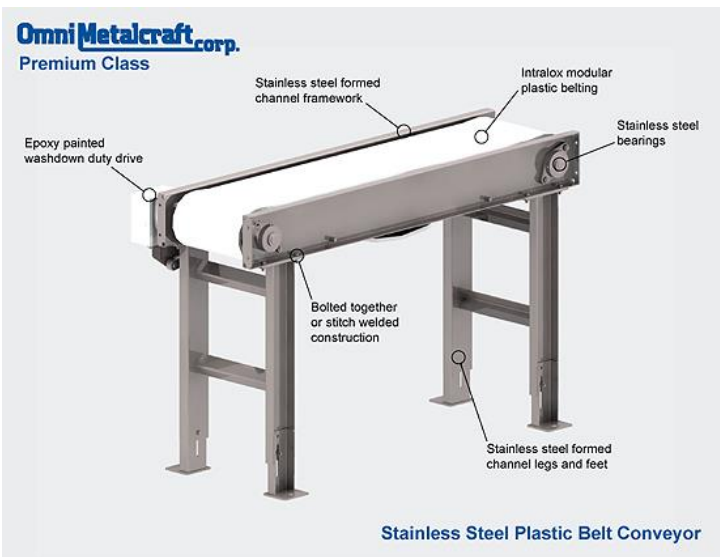

Gambar 5. Desain belt conveyor yang dirujuk 


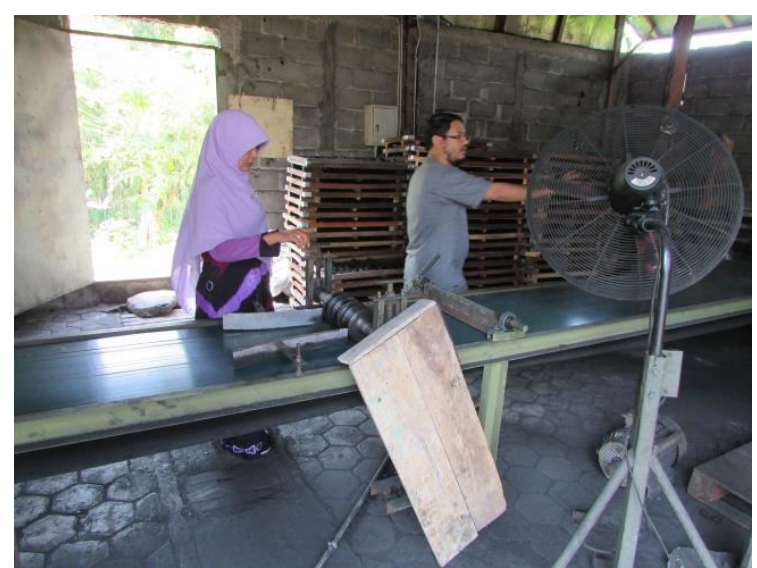

Gambar 6. Belt conveyor yang dihasilkan, panjang $8 \mathrm{~m}$ dan lebar $50 \mathrm{~cm}$

\section{Kesimpulan}

a. Tercapainya efisiensi produksi briket arang batok kelapa sekaligus alih teknologi dengan membuat mesin belt conveyor.

b. Terbentuknya manajemen keuangan yang rapih dengan pembelian software akuntansi serta melakukan pelatihan sekaligus monitoring evaluasi dalam penggunaannya.

c. Terciptanya peningkatan lapangan kerja melalui rekruitmen karyawan akuntansi dan karyawan produksi karena meningkatnya kapasitas produksi.

\section{UCAPAN TERIMA KASIH}

Ucapan terima kasih ditujukan kepada DP2M Dikti, Kopertis Wilayah V, LPPM UNISA, dan Zahir Enterprise.

\section{DAFTAR PUSTAKA}

Arfani, RN. (2013). GVC (Global Value Chain) Framework: Perspective \& Practices to Comprehend Local - Global Nexus in Trade Relations. Makalah untuk Short Course Series in International Trade (SCSIT) PSPD (Pusat Studi Perdagangan Dunia). UGM: Yogyakarta.

Downing J., Campbell, R. (2014). Briefing paper, The Value Chain Framework. USAID. Diunduh dari link

https://www.maxwell.syr.edu/uploadedFiles/exed/site s/pgppm/Program Readings/10 21 AbonyiValue Chain Framework.pdf.

Dunn, E., Sebstad, J., Batzdorff, L., and Parsons H. (2006). Lessons Learned on MSE Upgrading in Value Chains: A Synthesis Paper. AMAP BDS Knowledge and Practice

Kula, Olaf, Downing, J., Field, M. (2006). Globalization and the small firm: A value chain approach and poverty reduction. AMAP BDS Knowledge and Practice microREPORT \#42, USAID/G/EGAT/MD. Washington, D.C: ACDI/VOCA 